\title{
Growth Performance and Survivability of the Asian Seabass Lates Calcarifer Reared Under Hyper- Saline, Hypo-Saline and Freshwater Environments in a Closed Aquaculture System
}

Habib UI Hassan ( $\square$ habib5447@gmail.com )

University of karachi https://orcid.org/0000-0003-3326-0143

Qadeer Mohammad Ali

University of Karachi

Zubia Masood

University of Balochistan

Mohammad Abdul Momin Siddique

Noakhali Science and Technology University

\section{Research Article}

Keywords: Lates calcarifer, aquaculture, effects of salinity, growth, survival

Posted Date: March 10th, 2021

DOl: https://doi.org/10.21203/rs.3.rs-211072/v1

License: (c) (1) This work is licensed under a Creative Commons Attribution 4.0 International License.

Read Full License 


\section{Abstract}

Salinity is one of the most critical environmental parameters regarding fish physiology, modifying food intake and growth performance in many fish species. The present study has investigated the effects of different salinity levels on growth performance, feeding and survival of Asian seabass Lates calcarifer juveniles. Asian seabass juveniles were reared at 0, 5, 22, 36, and 42 ppt salinity. One five hundred ninetyeight fish individuals with an average weight $1.2 \pm 0.11 \mathrm{~g}$ were randomly distributed ( $166 \mathrm{fish} /$ Tank) in 5

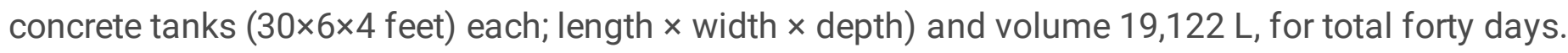
Initially feeding rate of $6 \%$ biomass per day with $42 \%$ crude protein-containing diets daily. The feeding rate adjusted according to fish biomass every week. The results showed that salinity level had a significant effect on the weight gain, average daily weight gain, specific growth rate, feed conversion ratio, survival rate, total biomass and health indices $(p<0.05)$. The highest WG $(39.11 \pm 1.49 \mathrm{~g}), A D W G$, ( $1.00 \pm 0.12 \mathrm{~g})$, SGR $\left(8.74 \pm 0.03 \% \mathrm{~d}^{-1}\right)$ and lowest FCR $(0.96 \pm 0.20)$ observed with T3 (22 ppt salinity) treatment, which was significantly higher compared to other treatment groups $(p<0.05)$. Among the health indices, the highest hepatosomatic index and viscerosomatic index found with $22 \mathrm{ppt}$ salinity treatment, which was also significantly higher than the other treatment groups $(p<0.05)$. No significant differences were found among the treatments in terms of survival rate $(p>0.05)$, but the maximum survival rate $(98.89 \pm 0.0 \%)$ in T3 (22 ppt) and T2 (5 ppt). The maximum level of crude proteins $(19.99 \pm 1.4 \%$ ) was found in the whole-body biochemical composition (\% of wet weight) of Asian sea bass juveniles in T3 treatment group reared at 22 ppt salinity. The second-order polynomial regression showed that 20 ppt salinity is optimum for the best growth of Asian sea bass. Thus, our present work would provide valuable information to the fish farmers for culturing the sea bass as well as its management along the inland and coastline of Pakistan.

\section{Introduction}

Lates calcarifer (Bloch, 1790) is commonly known as "Barramundi" or "giant sea perch" or "Asian sea bass" throughout the world. It is one of the most suitable species for aquaculture, its tolerance to broad environmental conditions, gregarious (readily school), delicately-flavoured tasty, nutritious meat and fast growth rate that can be reached to 1.5 to $3.0 \mathrm{~kg}$ in a year when its environmental conditions are kept optimum, the maximum weight is about $60 \mathrm{~kg}$ (Allen et al. 2002), with sustained high demand and market price in both domestic and export markets (Hassan et al. 2020a; Rao et al. 2013). Asian sea bass is a comparatively strong ecological tolerance that tolerates a broad range of salinity from freshwater to complete seawater from 0 to $56 \mathrm{ppt}$ salinity (FAO 2017). Salinity is a critical environmental factor which can highly effect on the physiology of aquatic organisms (Urbina \& Glover 2015). Asian seabass has wide physiological tolerances growing in marine, brackish, and freshwater (Anil et al., 2010; GanzonNaretetal 2013; Venkatachalam et al. 2018; Yue et al. 2009). Salinity also has an antagonistic effect on growth, survival, fecundity, physiology and osmoregulation (Smith 2003; Smith and Schindler 2009; Anni et al. 2016). Fish at the extreme of their salinity tolerance range often exceed their osmoregulation ability 
(Sampaio and Bianchini 2002). The rapid rise in salinity disrupts physiological procedures in fish, leading to greater cortisol concentrations in the blood (Tsuzuki et al. 2007).

Culture of L. calcarifer is relatively new in Pakistan (Shah et al. 2020), To initiate advance aquaculture, the development of breeding, larviculture and farming technology is an urgent need to increase and establish Asian sea bass culture industry throughout the country. Specific water parameters and seed production management are required for effective aquaculture practice to avoid the wild fisheries resources declining (Shah et al. 2020) for excellent growth performance and successful aquaculture necessary optimum parameters. Therefore, the objective of this study was to investigate the growth performance, survival, and health status of Asian seabass with a wide range of salinities in a closed aquaculture system.

\section{Materials And Methods}

\section{Experimental design}

The present study was conducted at the Sindh fish hatchery near Hawkes Bay town from March 2019 to Jan 2020. A total of 598 uniform sized (1.24 \pm 1.08 grams) sea bass juveniles were collected from the coastal area of Sindh Sakro and stocked (166 fish/Tank) in five treatments (T1, T2, T3, T4 and T5). Each treatment tank was $30 \times 6 \times 4$ feet containing $0,5,22,35$ and 42 ppt salinity by following the methods of Azodi et al. (2016) with some modifications. Tank water was regulated by blending filtered water from the ocean and freshwater. Water was exchanged for the maintenance of the water quality by up to $50 \%$ every 2 days. Fish were fed at $6 \%$ of body weight per day $\left(B W\right.$ day $\left.^{-1}\right)$ for 40 days and the feeding rate adjusted every week. The extracted pellet (42.0\% crude protein) was used for the manual feeding at two distinct satiation levels twice daily. After 3 hours of feeding, the extra feed was removed. The total consumption of food was reported daily in each treatment. A $42 \%$ CP-level diet was formed using various components (Table 1), referred to as the entire diet/ration structure. This diet was offered regularly based on the daily wet bodyweight of the individuals.

\section{Feed formulation and preparation}

Feed ingredients were collected from Karachi's local market and formulated as previously methods described by Ghosh et al. (2011). The major source of protein used in diets was fishmeal, and the levels of protein were preserved at $42 \%$. The feed ingredients have been combined to form a dough with fish oil and water. The palletizer was carried through the dough to create the necessary pellet diet. Under dry conditions, the feed was stored in a freezer until used. Proximate dry matter, crude fat, crude protein, crude fibres, and moisture levels were determined in a percentage of the dried feed specimens (Table 1).

\section{Samples collection and Biochemical analysis}

The biochemical analysis of feed and fish carcass samples was carried out based on (AOAC 2000). At the end of the experiment, five fish were removed from each tank and then dissected to weigh the liver 
and viscera, then HSI and VSI were determined. Techniques (AOAC 2000) were used to analyze crude lipid $(\mathrm{CL})$, moisture and crude protein (CP). Moisture was measured at $105^{\circ}$ Celsius in the oven for $24 \mathrm{~h}$ (Labostar-LG122 Tabia Espec, Osaka, Japan). Chloroform/methanol (2:1v/v) extraction process predicted for crude lipids. (Folch et al. 1957) The CP analyzed using the automatic processing of Kjeldahl (Buchi430/) Using the Kjeltec method (N 6.25) with the automatic Kjeldahl system (Buchi 430/323) Model 1265, Moline IL, USA). Furthermore, for the determination of ash, the sample was burned at $550 \mathrm{C}$ in a muffle furnace for 3 hours. Gross energy (GE) has been approximated for formulated diets factors 23.62, 39.5 and $17.56 \mathrm{KJ} / \mathrm{g}$ for CP, EE and carbohydrate respectively were used (NRC 1993).

\section{Water quality parameters}

Water quality parameters such as temperature, salinity, dissolved oxygen (DO), and pH were recorded daily using Celsius glass thermometer, Handheld Refractometer, mobile digital DO-meter (Model: HI9146) and Digital pH meter, respectively. The concentrations of ammonia, alkalinity, nitrate, and nitrite were measured by following the methods of APHA (1995). Details of the water quality parameters recorded during the study period are given in Table 2 .

\section{Growth performance analysis}

The wet weight gain, average daily weight gain (ADWG), specific growth rate (SGR), feed conversion ratio (FCR), hepatosomatic index (HSI), viscerosomatic index (VSI), Fulton's condition factor (CF), survival rate (SR) and total biomass were calculated with the following formula adopted by Hassan et al. (2020b):

WG=Final weight-initial weight

$A D W G=\{($ Final weight-Initial weight $) /$ Days $\}$

$\operatorname{SGR}(\%)=[(\operatorname{Ln} F B W-\operatorname{Ln}$ IBW $) /$ day $] \times 100$

FCR=Food given $(\mathrm{g}) /$ Weight gain $(\mathrm{g})$

Fulton's condition factor $(K)=\left(\right.$ Weight/Length $\left.{ }^{3}\right) \times 100$

VSI $=\{$ weight of visceral organs and associated fat tissue $(\mathrm{g}) /$ wet body weight $\} \times 100$

$\mathrm{HSI}=$ weight of liver $(\mathrm{g}) /$ empty fish weight $(\mathrm{g}) \times 100$

$\operatorname{SR}(\%)=($ No. of fish survived/ No. of fish released $) \times 100$

Cannibalism $(\%)=100 \times[($ LS $-M-$ LC $) / L S]$

Where, LS stocked at the beginning of sea bass, LC is the number of sea bass collected at the end of the study and $M$ is natural mortality

Biomass $=$ Average bodyweight $\times$ No of fish 


\section{Statistical analysis}

All data were analyzed using STATISTICA V.13 software (StatSoft Inc., Tulsa, OK, USA). Residuals were tested for normality (Shapiro-Wilk test) and homogeneity of variance (plot of residuals versus predicted values). The percentages data were natural $\log (\mathrm{LN})$-transformed before analysis. The effects of different salinity group on the growth performance and health indices of Asian seabass juveniles at different culture periods were analyzed using a repeated-measures ANOVA model containing culture period (fixed repeated factor) and different salinity groups (fixed factor) main effects as well the culture period $x$ different salinity groups interaction term. Then, the model was decomposed into a series of one-way ANOVA was run to test the effects of different salinity levels on the wet weight gain, average daily weight gain, specific growth rate, hepatosomatic index, viscerosomatic index, Fulton's condition factor, feed conversion ratio, survival rate and biomass for different culture periods. A posteriori analysis was performed using Tukey's multiple comparisons procedures. A significance level of $p<0.05$ was used for all statistical tests.

\section{Results}

\section{Physicochemical parameters}

Table 2 shows the minimum and maximum values of water quality parameters in five experimental groups recorded as water $\mathrm{pH}$ and the temperature was range from 8.10 to 8.81 and 29.40 to $29.74^{\circ} \mathrm{C}$, while dissolved oxygen (DO) was found in the range from 7.16 to $8.16 \mathrm{mg} / \mathrm{L}$, dissolved ammonia concentration was 0.012 to 0.072 ; whereas, alkalinity was between 126.1 to $162.4 \mathrm{mg} / \mathrm{L}$, nitrates from 0.004 to $2.57 \mathrm{mg} / \mathrm{L}$ and nitrates 0.010 to $0.014 \mathrm{mg} / \mathrm{L}$ respectively.

\section{Growth performance}

The saturated repeated-measures ANOVA model revealed a significant effect on the culture period $x$ different salinity groups interaction term $(p<0.01)$. Therefore, the model was decomposed into a series of a lower-order statistical model. Our results showed that salinity level had a significant effect on the weight gain, average daily weight gain, specific growth rate total biomass and health indices $(p<0.05)$ (Table 3). The highest weight gain ( $39.11 \pm 1.49 \mathrm{~g})$, average daily weight gain $(1.00 \pm 0.12 \mathrm{~g})$, specific growth rate $\left(8.74 \pm 0.03 \% \mathrm{~d}^{-1}\right)$ and production $(6654 \pm 4.20 \mathrm{~g})$ observed with $22 \mathrm{ppt}$ salinity treatment, which was significantly higher compared to other treatment groups $(p<0.05)$ followed by salinity $42 \mathrm{ppt}$ (T5), 36 ppt salinity (T4), 5 ppt and 0 ppt (T1) respectively. However, the growth curve decreased with increased salinity above 36 to $42 \mathrm{ppt}$. The second-order polynomial regression showed that $20 \mathrm{ppt}$ salinity is optimum for the best growth of Asian sea bass

\section{Feed utilization parameters}

The FCR value significantly variance among the groups (at level $\mathrm{P}<0.05$, Table 3 ). T3 had the best FCR $(0.96 \pm 0.20)$ followed by T1 $(1.24 \pm 0.10)$ T2 $(1.04 \pm 0.00)$ and T4 $(1.23 \pm 0.10)$ while the worst FCR was 
achieved by T1 $(1.47 \pm 0.20)$.

\section{Morphological indices}

Among the health indices, the highest hepatosomatic index and viscerosomatic index found with $22 \mathrm{ppt}$ salinity treatment, which was also significantly higher than the other treatment groups $(p<0.05)$. The better condition factor also found in T3 compared to other treatments.

\section{Cannibalism and survival}

However, no significant differences were found among the treatments in terms of survival rate $(p>0.05)$, but the maximum survival rate $(99.39 \pm 0.0 \%)$ in T3 (22 ppt). The cannibalism noted in T1 and T4 treatments.

\section{Proximate composition of fish carcass}

The proximate carcass composition was calculated on basis wet weight and presented in Table 4 carcass content of moisture and protein did not significantly affect by salinity. Conversely,

carcass content of lipid and ash significantly differed among the treatments, where lipid carcass of T1, $\mathrm{T} 2, \mathrm{~T} 3$ is lower compared to T4 and T5. The moisture content and protein in carcass did not significantly effect by salinity, were moisture of $\mathrm{T} 1$ is higher than the other treatments. There was a positive correlation between the carcass content of crude proteins and increasing of salinity level, The maximum level of crude proteins $(19.99 \pm 1.4 \%$ ) was found in the whole-body biochemical composition (\% of wet weight) of Asian seabass juveniles in T3 treatment group reared at $22 \mathrm{ppt}$ salinity (Table 4). Concerning Ash content, there was insignificant among T5, T4, T3 and T2 in Ash content, but Ash content of T1 was 7.82 \pm 0.1 and significantly higher than the other treatments.

\section{Discussion}

As Asian sea bass $L$. calcarifer has great commercial values among the other marine fish species because of its usage as popular cultured species in most Southeast Asian countries including Thailand, Taiwan, Indonesia, Malaysia, Singapore and Hong Kong near coastal water, brackish and also in their freshwaters resources. Most countries have now used this cultured species for both development and research purposes in pond and cage culture. In this study, the means of physicochemical parameters were recorded in Table 3, did not show and marked variation and fall between the acceptable range for Asian sea bass growth and heath According to (Priestly et al. 2006; Hassan et al. 2020a; Kungvankij et al. 1986), who also found water $\mathrm{pH}$ ranged from 7.5 to 8.3 , temperature 26 to $32^{\circ} \mathrm{C}$, dissolved oxygen (DO) from 4.0 to $8.0 \mathrm{mg} / \mathrm{L}$, Dissolved ammonia less than $0.02 \mathrm{mg} / \mathrm{L}$ and salinity was considered as 10.0 to $31.0 \mathrm{ppt}$ during culturing of fry and fingerling stages of $L$. calcarifer reared in concrete tanks near coastal waters in Thailand. Moreover, the nitrite and nitrate concentrations were comparatively low $(>5 \mathrm{mg} / \mathrm{L})$ in five experimental tanks of this study, because of addition of surface runoff water from rainfall bring pollutants includes domestic sewage wastes, agriculture and industrial wastes in fish ponds along with 
water resources used in fish culture and ammonium wastes from fish excreta released in fish ponds during culture of this species as in accordance with Christensen et al. (2012). Nitrate in ponds was higher than in canals because the decomposition of ammonia from fish waste to nitrate. However, nitrate was found in low concentration which meet the surface water quality criteria. Our results of water quality parameters was also found to be optimum for the growth of this species as reported by Jerry (2014). In addition, Abdullah et al. (2018) studied had shown the significant impact of dry and monsoon seasons on the water parameters includes salinity, dissolved oxygen concentration and turbidity of $L$. calcarifer culturing near Sri Tujuh lagoon of north east coast of Peninsular Malaysia.

In this study, the optimum salinity considered best for normal culture of seabass was $22 \mathrm{ppt}$ (T3), which was very close to the results obtained by Ercan et al. (2015). Cheong (1989) had reported that as $L$. calcarifer is a euryhaline species; therefore, it can be easily cultured in both freshwater and brackish water, or even in seawater also. Therefore, this species had been successfully cultured in the freshwater ponds various regions of the world like in Thailand, and also in coastal water ponds like in Tahiti with salinity ranging from 10 to 35 ppt. Hence, most farmers commonly cultured L. calcarifer in ponds located along the sea coast with salinities ranging between 10 to $30 \mathrm{ppt}$, which is considered the optimum range for this species. Euryhaline fish undergo a crucial stage during their acclimatization in a hyperosmotic environment. There is a rapid increase in the gill-ion fluid, followed by a rise in serum electrolytes and osmolality. In the present study, the acclimatization process for the juvenile fish was done to reduce the stress level of the fish during exposure to the different salinity treatments. The juvenile fish were not directly introduced to the various salinity treatments. Indeed, the salinity was decreased or increased slowly to the targeted level using a dropper to avoid fish startling. Thus, the juvenile can survive in a wide range of salinity without affecting its mortality rate (Cotton et al. 2003). In the present study, less mortality of juveniles was found for all the treatment groups ( 0 to 42 ppt salinity), which indicates that Asian seabass juveniles can resist abrupt hyper/hypoosmotic exposure. When fish have been questioned by medium salinity fluctuations, the ion concentration in body fluids has altered. This is in connection with the higher exchange layer on the skin and gut that lead to higher absorption of water (Shui et al. 2018).

Dendrinos \& Thorpe (1985) had reported the significant impact of various salinity levels ranged from 0.5 to $33 \%$ on growth and body composition of European bass Dicentrarchus labrax and found that juveniles can survive in salinities between 5 to $33 \%$. They also observed its maximum growth rate at $30 \%$, which was decreased with decreasing salinity from 20 to $25 \%$, and even died in freshwater with $0 \%$ within few days. However, such changes in salinity levels have no impact on proximate composition of fish body muscles. In the present study, various salinity levels effected on the growth performance and survival rate, where the best growth performance and survival rate were recorded in T3 (22 ppt salinity). The previous study of Bernardino et al. (2016) had also found that salinity is the main factor affecting fecundity, osmoregulation, growth rate, feed consumption and survival of fish. Rearing fish in high salinity conditions has the potential to suppress the appetite of the fish. Li et al. (2008), Partridge et al. (2008) studies suggested that decreasing growth in increased salinity was related to the decrease in food consumption. The hyper-saline environment at 42 ppt salinity negatively effects on the growth rate, 
oxygen consumption, histological changes of hepatopancreas and survival as previously reported by Li et al. (2007). L. calcarifer at the extreme salinity range often increase their ability for osmoregulation; therefore, Partridge et al. (2008) observed that $L$. calcarifer if reared in salinity levels ranged between 0 to $36 \mathrm{ppt}$, then its expected specific growth rate (SGR) of its juvenile stages can be obtained during its culture; however, if reared at 37 to $42 \mathrm{ppt}$ salinities, than its may negatively affect its both growth performance and survival rates during culture.

\section{Conclusion}

From the above study, it was concluded that the highest growth and survival of Asian seabass $L$. calcariferwere observed at $22 \mathrm{ppt}$ salinity as compared to the other salinity treatments. Therefore, we recommended 20 to $36 \mathrm{ppt}$ salinity for commercial farming of this species under a closed aquaculture system. Sympathetic the physiological capacity of Asian Sea bass to adapt environmental salinity changes reflecting the sustainability of investment possibilities in the aquaculture field. Using a distinct salinity concentration would maximize sea bass production and promote economic growth in aquaculture production.

\section{Declarations}

\section{Ethical approval and consent to participate}

This study was carried out in strict accordance with the recommendations by the Local Ethical Committee for Experiments on Animals of the University of Karachi, Pakistan

\section{Funding}

There was no funding from any funding body or grant agency for conducting this study.

\section{Availability of data and materials}

All data analyzed during this study are included in this manuscript.

\section{Consent to Publish}

Not applicable. This manuscript did not contain data from any individual person.

\section{Author Contributions}

Experimental design: HUH, QMA; Experiment conduct: HUH, QMA; Data analysis: ZM, KG; Manuscript writing: $H H, Q M A, A R, H R$ and MAMS Validating and reviewing.

\section{Conflict of Interest}

All authors declare no conflicts of interest. All authors listed in the manuscript contributed and attest to the validity and legitimacy of the data and its interpretation and agree to its submission to your journal. 
Acknowledgements

The authors are grateful for all the support from the FDB; MNFS\&R. We are indebted to the Department of Zoology (MRCC), University of Karachi for laboratory space

\section{References}

1. Anil N K, Santosh B, Jasmine S, Saleela KN, George RM, Kingsly HJ, Unnikrishnan C, Rao AH, Syda G (2010) Growth performance of sea bass Lates calcarifer (Bloch) in sea cages at Vizhinjam Bay along the south-west coast of India. Indian J Fish 574: 65-69. http://eprints.cmfri.org.in/id/eprint/7808

2. Anni ISA, Bianchini A, Barcarolli IF, Varela AS, Robaldo RB, Tesser MB, et al. (2016) Salinity influence on growth, osmoregulation and energy turnover in juvenile pompano Trachinotus marginatus Cuvier 1832. Aquaculture 455: 63-72. https://doi.org/10.1016/j.aquaculture.2016.01.010

3. APHA (American Public Health Association), (1995) Standard methods for the examination of water and wastewater,19th ed. American Public Health Association, Washington, DC.

4. Azodi M, Bahabadi MN, Morshedi V, Ebrahimi H, Hamedi S (2016) The effects of different levels of water salinity on growth, feeding performance, body composition and physiologica responses in Asian sea bass (Lates calcarifer). JFST 5( 1):99-111. http://jfst.modares.ac.ir/article-6-9513-en.html

5. Abdullah H, Rak A, Wei L (2018) The impacts of monsoon and dry seasons on physical water quality changes and farmed Asian seabass Lates calcarifer (Bloch, 1790) mortality at Sri Tujuh lagoon. AACL Bioflux 11(1):167-182. http://www.bioflux.com.ro/docs/2018.167-183.pdf

6. AOAC Assn. of Official Analytical Chemists., 2000. Coffee and tea. In: Official methods of analysis. 17th ed. Gaithersburg, Md. : AOAC.

7. Bernardino RJ, Fernandes C (2016) Growth performance for European sea bass fingerlings, Dicentrarchus labrax, reared at different salinities. Front. Mar. Sci. Conference Abstract: IMMR International Meeting on Marine Research 2016. https://doi.org/ 10.3389/conf.FMARS.2016.04.00031

8. Cotton CF, Walker RL, Recicar TC (2003) Effects of Temperature and Salinity on Growth of Juvenile Black Sea Bass, with Implications for Aquaculture. North American Journal of Aquaculture 65: 330338, https://doi.org/ 10.1577/C02-037

9. Cheong $L$ (1989) Status of knowledge on farming of seabass (Lates calcarifer) in South East Asia. Actes de colloques Ifremer, Tahiti, French Polynesia 20 Feb - 4 Mar 1989 n9, chap 39:421428. https://archimer.ifremer.fr/doc/00000/1467/

10. Christensen VG, Lee KE, McLees JM, Niemela SL (2012) Relations between Retired Agricultural Land, Water Quality, and Aquatic-Community Health, Minnesota River Basin. J Environ. Qual 41:1459-1472. https://doi.org/10.2134/jeq2011.0468

11. Dendrinos P, Thorpe JP (1985) Effects of reduced salinity on growth and body composition in the European bass Dicentrarchus labrax (L.). Aquaculture 49(3-4): 333-358. https://doi.org/10.1016/0044-8486(85)90090-0. 
12. Ercan E, Ağral N, Tarkan AS (2015) The Effects of Salinity, Temperature and Feed Ratio on Growth Performance of European Sea Bass in the Water Obtained Through Reverse Osmosis System and a Natural River. Pakistan J Zool 47(3): 625-633, 2015.

13. Food and Agriculture Organization (FAO) (2017) Fishstat Plus Version 2.30. FAO Fisheries Department, Fishery Information, Data and Statistics Unit. http://www.fao.org./fi/statist/FISOFT/FISHPLUS. Accessed on 24 February 2017.

14. Folch J, Lees M, Stanley G S (1957) A simple method for the isolation and purification of total lipides from animal tissues. J Biol Chem 226 (1): 497-509.

15. Ganzon-Naret E S, (2013) Growth response and feed intake of Lates calcarifer to four different dietary protein levels with green pea (Pisum sativum) under controlled laboratory. ABAH Bioflux 52:137- 144. http://www.abah.bioflux.com.ro/docs/2013.137-144.

16. Ghosh D, Sathianandan TV, Vijayagopal P (2011) Feed Formulation Using Linear Programming for Fry of Catfish, Milkfish, Tilapia, Asian Sea Bass, and Grouper in India. Journal of Applied Aquaculture 23(1):85-101, https://doi.org/10.1080/10454438.2011.549781

17. Hassan HU, Ali QM, Ahmad N, Masood Z, Hossain MY, Gabol K, Khan W, Hussain M, Ali A, Attaullah M, Kamal M (2020a) Assessment of growth characteristics, the survival rate and body composition of Asian Sea bass Lates calcarifer (Bloch, 1790) under different feeding rates in closed aquaculture system. Saudi J Biol Sci https://doi.org/10.1016/j.sjbs.2020.11.056

18. Hassan HU, Ali QM, Rahman MA, Kamal M, Tanjin S, Farooq, U, Mawa Z, Badshah N, Mahmood K, Hasan MR, Gabool K, Rima FA, Islam MA, Rahman O, Hossain MY (2020b) Growth pattern, condition and prey-predator status of 9 fish species from the Arabian Sea (Baluchistan and Sindh), Pakistan. Egypt J Aquat Biol 24: 281 - 292. https://dx.doi.org/10.21608/ejabf.2020.97439

19. Jerry DR (2014) Biology and Culture of Asian Seabass Lates calcarifer. LLC CRC Press is an imprint of Taylor \& Francis Group, International Standard Book Number-13: 978-1- 4822-0808-5 (eBook PDF). https://ph01.tci-thaijo.org/index.php/VESTSU/article/download/207605/158939

20. Kungvankij P, Tiro LB, Pudadera BJJr,Potesta IO (1986) Biology and culture of seabass (Lates calcarifer), NACA Training Manual Series No. 3, NACA/RLCP. Bangkok, 70 p.

21. Li E, Chen L, Zeng C, Yu N, Xiong Z, Chen X, (2008) Comparison of digestive and antioxidant enzymes activities, haemolymph oxyhemocyanin contents and hepatopancreas histology of white shrimp, Litopenaeus vannamei at various salinities. Aquaculture 274:80-86.

22. Li EC, Chen LQ, Zeng C, Chen XM, Yu N, Lai QM, Qin JG ( 2007) Growth, body composition, respiration and ambient ammonia nitrogen tolerance of the juvenile white shrimp, Litopenaeus vannamei, at different salinities. Aquaculture 265: 385-390. https://doi.org/10.1016/j.aquaculture.2007.02.018

23. Partridge GJ, Lymbery AJ (2008) The effect of salinity on the requirement for potassium by barramundi (Lates calcarifer) in saline groundwater. Aquaculture 278:164-170. https://doi.org/10.1016/j.aquaculture.2008.03.042

24. Priestley SM, Stevenson AE, Alexander LG(2006) The influence of feeding frequency on growth and body condition of the common goldfish (Carassius auratus). The Journal of Nutrition 136:1979S- 
1981S. https://doi.org/10.1093/jn/136.7.1979S

25. Rao G S, Joseph I, Philipose KK, Mojjada SK (2013) Cage aquaculture in India. Central Marine Fisheries Research Institute. Kochi. 233 pp. http://eprints.cmfri.org.in/id/eprint/11222

26. Sampaio LA, Bianchini A (2002) Salinity effects on osmoregulation and growth of the euryhaline flounder Paralichthys orbignyanus. J Exp Mar Biol Ecol 269(2): 187-196. https://doi.org/10.1016/S0022-0981(01)00395-1

27. Shah SBH, Yongtong M, Narejo NT, Jarwarc A, Oadd S, Alia M, Lia Y, Nisara U (2020) Economic analysis of Barramundi (Lates calcarifer) (Bloch 1790), in Pakistan and opportunities for its aquaculture development. Indian J Mar Sci 49 (08):1425-1434.

28. Shui C, Shi Y, Hua X, Zhang Z, Zhang H, Genhai LU, Xie Y (2018) Serum osmolality and ions, and gill Nap/Kp-ATPase of spottedtail goby Synechogobius ommaturus (R.) in response to acute salinity changes. Int J Fish Aquac 3:79-83. https://doi.org/10.1016/j.aaf.2018.03.002

29. Smith VH, Schindler DW (2009) Eutrophication science: where do we go from here Trends Ecol Evol 24, 201-207. https://doi.org/10.1016/j.tree.2008.11.009

30. Smith VH (2003). Eutrophication of freshwater and coastal marine ecosystems a global problem. Environ Sci Pollut Res 10: 126-139. https://doi.org/10.1065/espr2002.12.142

31. SPSS (2007) Statistical Package for Social Science (for Windows). Release 16 Copyright @ , SPSS Inc., Chicago, USA.

32. Tsuzuki MY, Ogawa K, Strüssmann CA, Maita M, Takashima F, Melo C M R (2007) The significance of cortisol on acclimation to salinity in pejerrey Odontesthes bonariensis. Arq Bras Med Vet Zootec 59(5): 1301-1307. https://doi.org/10.1590/S0102-09352007000500030

33. Urbina MA, Glover CN (2015) Effect of salinity on osmoregulation, metabolism and nitrogen excretion in the amphidromous fish, inanga (Galaxias maculatus). J Exp Mar Biol Ecol 473: 7-15. https://doi.org/10.1016/j.jembe.2015.07.014

34. Venkatachalam S, Kandasamy K, Krishnamoorthy I, Narayanasamy R (2018) Survival and growth of fish (Lates calcarifer) under integrated mangrove aquaculture and open-aquaculture systems. Aquaculture 9:18-24. https://doi.org/10.1016/j.aqrep.2017.11.004

35. Yue GH, Zhu ZY, Lo LC (2009) Genetic variation and population structure of Asian seabass (Lates calcrifer) in the Asia Pacific region. Aquaculture 293: 22-28. https://doi.org/10.1016/j.aquaculture.2009.03.053

\section{Tables}


Table 1

Feed ingredients of the experimental diet and biochemical composition of the prepared diets used for Asian seabass.

\begin{tabular}{|c|c|}
\hline Ingredients (\%) & Diet (\%) \\
\hline Fish meal & 41.0 \\
\hline Shrimp meal & 5.5 \\
\hline Soybean meal & 24.5 \\
\hline Squid meal & 4.4 \\
\hline Rice bran & 7.5 \\
\hline Bread flour & 4.4 \\
\hline Cod liver oil & 5.4 \\
\hline Mineral and vitamin premix & 6.0 \\
\hline Fish protein Hydrolysate & 1.3 \\
\hline Total & 100 \\
\hline \multicolumn{2}{|c|}{ Biochemical composition of diet (\%) ${ }^{1}$} \\
\hline Crude protein ${ }^{2}$ & $41.8 \pm 0.5$ \\
\hline Crude fiber & $9.1 \pm 0.5$ \\
\hline Crude lipid & $8.5 \pm 0.06$ \\
\hline ASH & $9.3 \pm 0.5$ \\
\hline Moisture & 10.8 \\
\hline Nitrogen-free extract ${ }^{3}$ & $31.30 \pm 0.5$ \\
\hline $\mathrm{P} / \mathrm{E}$ (mg crude protein $\mathrm{KJ}^{-1}$ & $14.7 \pm 0.5$ \\
\hline Energy $\left(\mathrm{kJg}^{-1}\right)$ & $24.5 \pm 0.6$ \\
\hline \multicolumn{2}{|l|}{ Note: } \\
\hline \multicolumn{2}{|c|}{${ }^{1}$ Dry matter basis (\%): mean \pm SE, number of determinations $=5$} \\
\hline \multicolumn{2}{|l|}{${ }^{2}$ Measured as nitrogen $\times 6.25$. } \\
\hline${ }^{3}$ Nitrogen-free extract $=100$ & $\%$ fiber $+\%$ ash \\
\hline
\end{tabular}


Table 2

Water quality parameters of four experimental tanks at Sindh Fish Hatchery recorded during the experimental period extends from March 2019 to Jan 2020

\begin{tabular}{|c|c|c|c|c|c|}
\hline \multirow[t]{2}{*}{ Water parameter } & \multicolumn{5}{|l|}{ Treatments } \\
\hline & T1 (0ppt) & T2 (5ppt) & T3 (22 ppt) & T4(36 ppt) & T5 (42 ppt) \\
\hline $\mathrm{pH}$ & $8.10 \pm 0.24$ & $8.40 \pm 0.22$ & $8.60 \pm 0.26$ & $8.80 \pm 0.29$ & $8.81 \pm 0.28$ \\
\hline Temperature $\left({ }^{\circ} \mathrm{C}\right)$ & $29.40 \pm 1.25$ & $29.60 \pm 1.25$ & $29.62 \pm 1.10$ & $29.74 \pm 1.31$ & $29.74 \pm 1.10$ \\
\hline D.O (mg/L) & $8.16+1.20$ & $7.16+1.20$ & $7.95 \pm 0.07$ & $8.03 \pm 0.25$ & $7.98 \pm 0.08$ \\
\hline $\begin{array}{l}\text { Ammonia } \\
(\mathrm{mg} / \mathrm{L})\end{array}$ & $\begin{array}{l}0.013 \pm \\
0.005\end{array}$ & $0.012 \pm 0.005$ & $0.011 \pm 0.005$ & $0.072 \pm 0.112$ & $0.013 \pm 0.005$ \\
\hline Alkalinity (mg/L) & $126.1 \pm 5.56$ & $143.1 \pm 5.56$ & $147.4 \pm 5.07$ & $152.6 \pm 5.03$ & $162.4 \pm 5.07$ \\
\hline Nitrite (mg/L) & $\begin{array}{l}0.010 \pm \\
0.004\end{array}$ & $0.012 \pm 0.004$ & $0.013 \pm 0.005$ & $0.013 \pm 0.007$ & $0.014 \pm 0.005$ \\
\hline Nitrate (mg/L) & $\begin{array}{l}0.004 \pm \\
0.001\end{array}$ & $2.22 \pm 0.373$ & $2.32 \pm 0.20$ & $2.418 \pm 0.48$ & $2.572 \pm 0.20$ \\
\hline
\end{tabular}


Table 3

The effect of different salinity levels $(0,5,22,36 \& 42 \mathrm{ppt})$ on growth performance, morphological indices and survival of Asian seabass.

\begin{tabular}{|c|c|c|c|c|c|}
\hline \multirow[t]{2}{*}{ Biotechnical parameters } & \multicolumn{5}{|c|}{ Salinity level } \\
\hline & T1 (0 ppt) & T2 (5 ppt) & $\begin{array}{l}\text { T3 (22 } \\
\text { ppt) }\end{array}$ & $\mathrm{T} 4(36 \mathrm{ppt})$ & T5 (42 ppt) \\
\hline Initial body weight (g) & $1.22 \pm 0.43$ & $1.22 \pm 0.43$ & $1.22 \pm 0.35$ & $1.22 \pm 0.43$ & $1.23 \pm 0.46$ \\
\hline Final body weight (g) & $\begin{array}{l}37.80 \pm \\
0.45^{\mathrm{b}}\end{array}$ & $\begin{array}{l}38.20 \pm \\
0.42^{b}\end{array}$ & $\begin{array}{l}40.33 \pm \\
1.84^{\mathrm{a}}\end{array}$ & $\begin{array}{l}37.10 \pm \\
0.40^{\mathrm{b}}\end{array}$ & $\begin{array}{l}36.50 \pm \\
1.06^{\mathrm{b}}\end{array}$ \\
\hline Weight gain (g) & $\begin{array}{l}36.38 \pm \\
0.02^{\mathrm{b}}\end{array}$ & $\begin{array}{l}37.28 \pm \\
0.01^{\mathrm{b}}\end{array}$ & $\begin{array}{l}39.11 \pm \\
1.49^{\mathrm{a}}\end{array}$ & $\begin{array}{l}36.12 \pm \\
0.03^{b}\end{array}$ & $\begin{array}{l}34.28 \pm \\
0.39^{b}\end{array}$ \\
\hline $\begin{array}{l}\text { Average daily weight gain } \\
\text { (g/day) }\end{array}$ & $\begin{array}{l}0.90 \pm \\
0.11^{\mathrm{b}}\end{array}$ & $\begin{array}{l}0.94 \pm \\
0.09^{b}\end{array}$ & $\begin{array}{l}1.00 \pm \\
0.12^{\mathrm{a}}\end{array}$ & $\begin{array}{l}0.89 \pm \\
0.08^{\mathrm{c}}\end{array}$ & $\begin{array}{l}0.88 \pm \\
0.06^{c}\end{array}$ \\
\hline Specific growth rate $\left(\% \mathrm{~d}^{-1}\right)$ & $\begin{array}{l}8.57 \pm \\
0.01^{b}\end{array}$ & $\begin{array}{l}8.65 \pm \\
0.03^{b}\end{array}$ & $\begin{array}{l}8.74 \pm \\
0.03^{\mathrm{a}}\end{array}$ & $\begin{array}{l}8.53 \pm \\
0.02^{b}\end{array}$ & $\begin{array}{l}8.47 \pm \\
0.04^{\mathrm{c}}\end{array}$ \\
\hline Hepatosomatic index (HSI) & $\begin{array}{l}1.30 \pm \\
0.13^{b}\end{array}$ & $\begin{array}{l}1.30 \pm \\
0.32^{b}\end{array}$ & $\begin{array}{l}1.40 \pm \\
0.06^{\mathrm{a}}\end{array}$ & $\begin{array}{l}1.30 \pm \\
0.12^{b}\end{array}$ & $\begin{array}{l}1.20 \pm \\
0.01^{\mathrm{c}}\end{array}$ \\
\hline Viscerosomatic index (VSI) & $\begin{array}{l}3.50 \pm \\
0.21^{c}\end{array}$ & $\begin{array}{l}4.60 \pm \\
0.11^{\mathrm{b}}\end{array}$ & $\begin{array}{l}4.80 \pm \\
0.31^{\mathrm{a}}\end{array}$ & $\begin{array}{l}4.50 \pm \\
0.21^{\mathrm{b}}\end{array}$ & $\begin{array}{l}3.30 \pm \\
0.11^{\mathrm{c}}\end{array}$ \\
\hline Condition factor & $\begin{array}{l}1.50 \pm \\
0.04^{\mathrm{a}}\end{array}$ & $\begin{array}{l}1.38 \pm \\
0.06^{\mathrm{b}}\end{array}$ & $\begin{array}{l}1.17 \pm \\
0.02^{\mathrm{c}}\end{array}$ & $\begin{array}{l}1.68 \pm \\
0.06^{\mathrm{a}}\end{array}$ & $\begin{array}{l}1.41 \pm \\
0.21^{\mathrm{b}}\end{array}$ \\
\hline Feed conversion ratio & $\begin{array}{l}1.24 \pm \\
0.10^{\mathrm{b}}\end{array}$ & $\begin{array}{l}1.04 \pm \\
0.00^{c}\end{array}$ & $\begin{array}{l}0.96 \pm \\
0.20^{c}\end{array}$ & $\begin{array}{l}1.23 \pm \\
0.10^{\mathrm{b}}\end{array}$ & $\begin{array}{l}1.47 \pm \\
0.20^{\mathrm{a}}\end{array}$ \\
\hline Cannibalism (\%) & $\begin{array}{l}2.40 \pm \\
0.00^{\mathrm{a}}\end{array}$ & $\begin{array}{l}0.00 \pm \\
0.00^{\mathrm{a}}\end{array}$ & $\begin{array}{l}0.00 \pm \\
0.00^{\mathrm{a}}\end{array}$ & $\begin{array}{l}1.20 \pm \\
0.00^{\mathrm{a}}\end{array}$ & $\begin{array}{l}0.00 \pm \\
0.00^{\mathrm{a}}\end{array}$ \\
\hline Survival rate (\%) & $\begin{array}{l}97.59 \pm \\
0.0^{\mathrm{a}}\end{array}$ & $\begin{array}{l}98.79 \pm \\
0.0^{\mathrm{a}}\end{array}$ & $\begin{array}{l}99.39 \\
\pm .0 .0^{\mathrm{a}}\end{array}$ & $\begin{array}{l}97.23 \pm \\
0 . .0^{\mathrm{a}}\end{array}$ & $\begin{array}{l}96.98 \pm \\
0.0^{\mathrm{a}}\end{array}$ \\
\hline Total biomass (g) & $\begin{array}{l}5893 \pm \\
4.12^{\mathrm{c}}\end{array}$ & $\begin{array}{l}6113 \pm \\
3.59^{\mathrm{b}}\end{array}$ & $\begin{array}{l}6654 \pm \\
4.20^{\mathrm{b}}\end{array}$ & $6010 \pm 22^{d}$ & $5876 \pm 43^{a}$ \\
\hline
\end{tabular}


Table 4

Whole-body biochemical composition (\% of wet weight) of L. calcarifer at different salinity level.

\begin{tabular}{|llllll|}
\hline Ingredients (\%) & \multicolumn{3}{l}{ Salinity Level } & & \\
\cline { 2 - 6 } & T1 (0 ppt) & T2 (5 ppt) & T3 (22 ppt) & T4 (36 ppt) & T5 (42 ppt) \\
\hline Crude proteins (\%) & $18.80 \pm 1.2^{\mathrm{b}}$ & $19.03 \pm 1.2^{\mathrm{ab}}$ & $19.99 \pm 1.4^{\mathrm{a}}$ & $19.80 \pm 1.4^{\mathrm{b}}$ & $19.02 \pm 1.4^{\mathrm{ab}}$ \\
\hline Crude lipids (\%) & $8.30 \pm 0.60^{\mathrm{ab}}$ & $8.80 \pm 0.60^{\mathrm{a}}$ & $8.40 \pm 0.8^{\mathrm{b}}$ & $8.30 \pm 0.7^{\mathrm{c}}$ & $8.29 \pm 0.77^{\mathrm{b}}$ \\
\hline Moisture (\%) & $70.20 \pm 1.1^{\mathrm{a}}$ & $69.10 \pm 2.1^{\mathrm{a}}$ & $69.30 \pm 1.2^{\mathrm{a}}$ & $69.50 \pm 2.5^{\mathrm{a}}$ & $69.60 \pm 2.5^{\mathrm{a}}$ \\
\hline Ash (\%) & $7.82 \pm 0.1^{\mathrm{b}}$ & $7.62 \pm 0.2^{\mathrm{b}}$ & $7.41 \pm 0.3^{\mathrm{b}}$ & $6.90 \pm 0.8^{\mathrm{a}}$ & $6.85 \pm 0.6^{\mathrm{a}}$ \\
\hline $\begin{array}{l}\text { Values are the mean } \pm \text { SE of groups in the same row with different superscripts are significantly } \\
\text { different (p>0.05). }\end{array}$
\end{tabular}

Figures

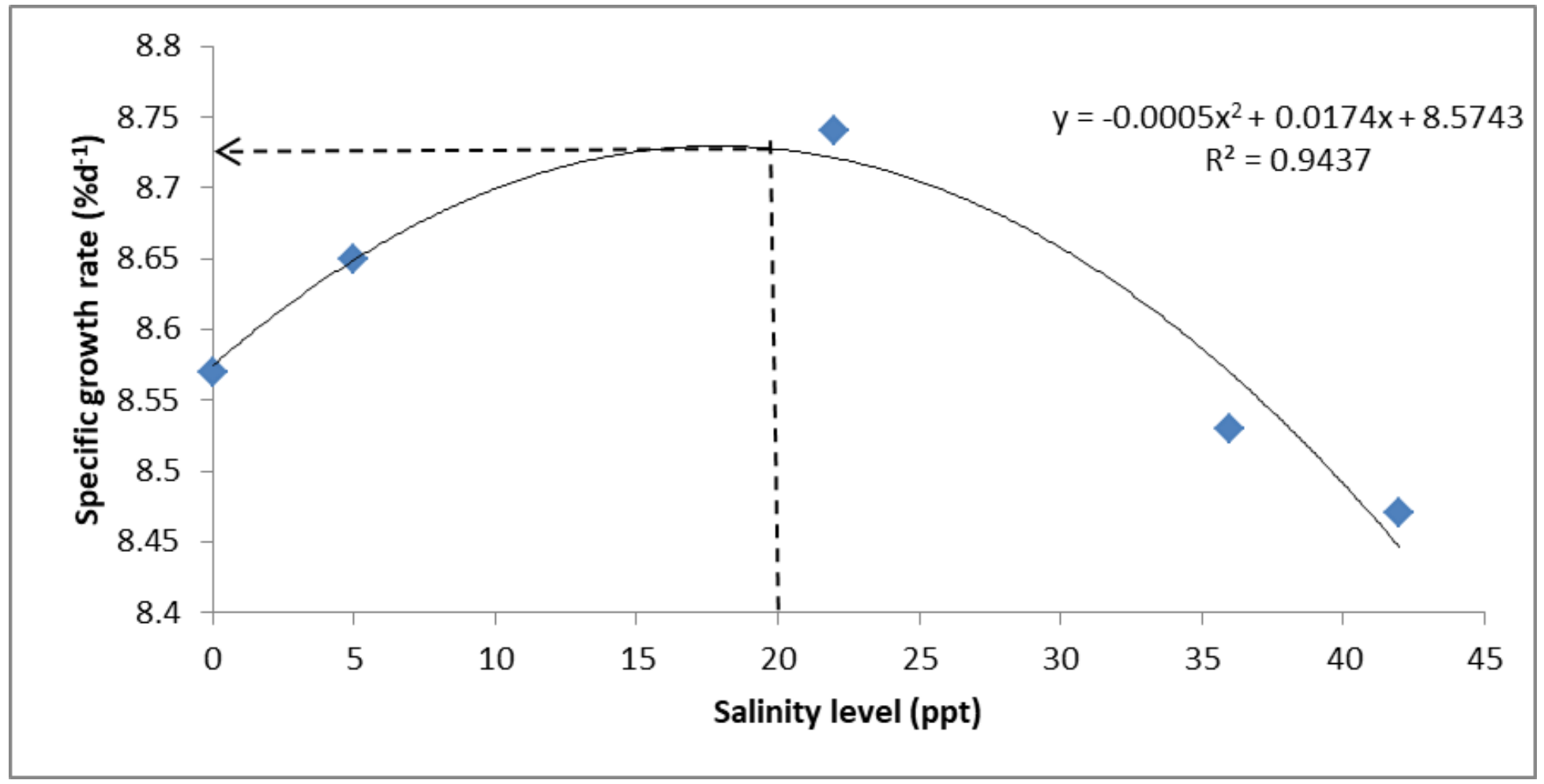

Figure 1

Second order polynomial regression between specific growth rate (SGR \%/d) and salinity levels shows that Asian seabass, 20 ppt salinity optimum for growth performance. 